\title{
Genetic structure of Leptopilina boulardi populations from different climatic zones of Iran
}

Majeed Askari Seyahooei ${ }^{1,2^{*}}$, Jacques JM van Alphen ${ }^{3}$, Ken Kraaijeveld ${ }^{1}$

\begin{abstract}
Background: The genetic structure of populations can be influenced by geographic isolation (including physical distance) and ecology. We examined these effects in Leptopilina boulardi, a parasitoid of Drosophila of African origin and widely distributed over temperate and (sub) tropical climates.

Results: We sampled 11 populations of L. boulardi from five climatic zones in Iran and measured genetic differentiation at nuclear (Amplified Fragment Length Polymorphism; AFLP) and mitochondrial (Cytochrome Oxidase I; COI) loci. An Analysis of Molecular Variance (AMOVA) for the AFLP data revealed that $67.45 \%$ of variation resided between populations. No significant variation was observed between climatic zones. However, a significant difference was detected between populations from the central (dry) regions and those from the wetter north, which are separated by desert. A similarly clear cut genetic differentiation between populations from the central part of Iran and those from the north was observed by UPGMA cluster analysis and Principal Coordinates Analysis (PCO). Both UPGMA and PCO further separated two populations from the very humid western Caspian Sea coast (zone 3) from other northern populations from the temperate Caspian Sea coastal plain (zone 2), which are connected by forest. One population (Nour) was genetically intermediate between these two zones, indicating some gene flow between these two groups of populations. In all analyses a mountain population, Sorkhabad was found to be genetically identical to those from the nearby coastal plain (zone 2), which indicates high gene flow between these populations over a short geographical distance. One population from the Caspian coast (Astaneh) was genetically highly diverged from all other populations. A partial Mantel test showed a highly significant positive correlation between genetic and geographic distances, as well as separation by the deserts of central Iran. The COI sequences were highly conserved among all populations.

Conclusion: The Iranian populations of L. boulardi showed clear genetic structure in AFLP profiles, but not in COI sequence data. The transfer of fruits containing Drosophila larvae parasitized by L. boulardi appears to have caused some unexpected gene flow and changed the genetic composition of populations, particularly in urban areas. Nevertheless, our results suggest that climate, geographic distance and physical barriers may all have contributed to the formation of genetically distinct populations of L. boulardi. Inevitably, there will be overlap between the portions of variance explained by these variables. Disentangling the relative contributions of climate and geography to the genetic structure of this species will require additional sampling.
\end{abstract}

\section{Background}

Changing climates are expected to have profound effects on the genetics of insect populations. One way to study such effects is to compare populations of a widely distributed organism across contrasting climates.

\footnotetext{
* Correspondence: askarisey@gmail.com

${ }^{1}$ Institute of Biology, Leiden University, P.O.Box 9505, 2300 RA Leiden, the Netherlands

Full list of author information is available at the end of the article
}

One of the main constraints on local genetic differentiation and adaptation is extensive gene flow between populations. Reduced dispersal between populations can lead to genetic subdivision of populations [1] and may facilitate local adaptation. Environmental or physical barriers may promote isolation of populations. These include geographic distance [2] and physical barriers like mountains, rivers and stretches of unsuitable habitat.

\section{Ciomed Central}

() 2011 Seyahooei et al; licensee BioMed Central Ltd. This is an Open Access article distributed under the terms of the Creative Commons Attribution License (http://creativecommons.org/licenses/by/2.0), which permits unrestricted use, distribution, and reproduction in any medium, provided the original work is properly cited. 
DNA markers provide powerful and efficient tools to study genetic diversity in insect populations [3-5] at both inter- and intraspecific level. Amplified Fragment Length Polymorphism (AFLP) is a useful DNA fingerprinting technique to study genetic diversity within a species [6-9] because it allows detection of genetic variation of organisms based on DNA from any source and complexity [10] without prior knowledge of the gene structure or sequences. AFLP markers have been used to infer the role of geographical distance and barriers to gene flow in shaping the genetic structure of population [e.g., [11-13]] in a variety of organisms. The results of AFLP analysis can be translated to the genetic distances $[4,8,14]$ of populations. Genetic distance of isolated population is the most fundamental information need to assess the role of geographical barriers and distances in genetic diversification of populations. Mitochondrial markers have also been used in population genetic studies [e.g., [15-17]] of insects. For example, in the ant Leptothorax rugatulus [16] a mitochondrial marker was found to be more informative than microsatellites and discriminated significantly better between populations. Using mitochondrial markers may provide valuable information on the migration of females between populations because mitochondria are maternally inherited.

Insect parasitoids have been a favorite model in ecology and evolutionary biology [18] studies. Drosophila parasitoids have played a major role in these studies, because of their ease of maintenance in the laboratory, the enormous biological and genetic information on their Drosophila host, which has been used as model organism for almost a century [19] and because of their diversity which allows comparative studies. In the present study we used AFLP markers and mitochondrial gene sequencing to investigate the role of geographical distance in shaping genetic variation in Iranian Leptopilina boulardi (Hymenoptera: Figitidae) populations. L. boulardi is a larval parasitoid of Drosophila of African origin [20] which is widely distributed over tropical and warm temperate regions. We used both AFLP and COI gene sequencing to study the genetic structure among 11 populations of L. boulardi collected from five contrasting climate zones in Iran (Figure 1, Table 1). The zones were chosen to represent five distinct climates varying in precipitation, length of season and minimum and maximum temperatures. The main goal of this study was to investigate to what extent the genetic structure of these populations matched climatic and geographical patterns.

\section{Results}

\section{AFLP analysis}

The 9 primer combinations yielded 670 scorable bands of which 147 (21.94\%) were polymorphic. AMOVA of the AFLP results revealed that the main proportion of genetic variation resided among populations $(67.45 \%$, $\mathrm{P}<0.001)$. Pair-wise differences of $F_{s t}$ values among populations ranged from 0.53 - 0.94 (Additional file 1). No significant differences were observed between populations from different climate zones. However, a significant proportion of variation was explained by the distinction between central and northern populations (18.1\%, P = 0.017). Consistent with AMOVA, UPGMA tree and bootstrap analysis indicated that the three populations from the central part of Iran (Dorcheh, Khairabad and Zamankhan) clustered together, but were differentiated from the northern populations sampled along the Caspian Sea coast (bootstrap value $=87 \%$, Figure 2). One population from the very wet Caspian Sea coast (Astaneh) was considerably different from all other populations. In pair-wise comparison of population the highest $F_{s t}$ values was observed when we compared this population with the others. UPGMA tree also separated this population strongly from all other with high bootstrap value (bootstrap $=88$ ). The Sorkhabad population, collected from a mountainous region on the slope of the Damavand mountain near Mazandaran clustered together with the wet Caspian Sea coastal populations. Consistent with UPGMA tree and PCO plots, low $F_{s t}$ values in pair-wise comparison were observed when we compared Sorkhabad with other northern populations (e.g. Chalus: $F_{s t}=0.53$ ).

Principal Coordinates Analysis (PCO) revealed informative separation of populations (Figure 3). The first three coordinates explained $69.32 \%$ of AFLP variation. By plotting the first two coordinates (which together explained $52.73 \%$ of the AFLP variation) the three populations from the dry central region of Iran clustered separately from the northern populations. These two principal coordinates also separated the populations from the two northern zones (zone 2 and 3), except Nour - a population from zone 2 clustered as zone 3 and Astaneh - the most divergent population which stood apart from all others. The other two PCO plots showed further evidence for divergence among the populations along the Caspian Sea coast. By plotting the first and third coordinates and second and third coordinates (which in total explained $46.67 \%$ and $39.26 \%$ of AFLP variation, respectively) two clusters were evident among the populations from the Caspian Sea coast, while Astaneh, the most divergent population, again stood apart from all other groups. Furthermore, the Zamankhan population from a Mediterranean climate (zone 5) appeared separated from the two other central populations from zone 4. (Khairabad and Dorcheh). Consistent with the UPGMA analysis, the Sorkhabad population from the mountain region clustered with populations from the geographically close, but ecologically different wet Caspian Sea coast. 


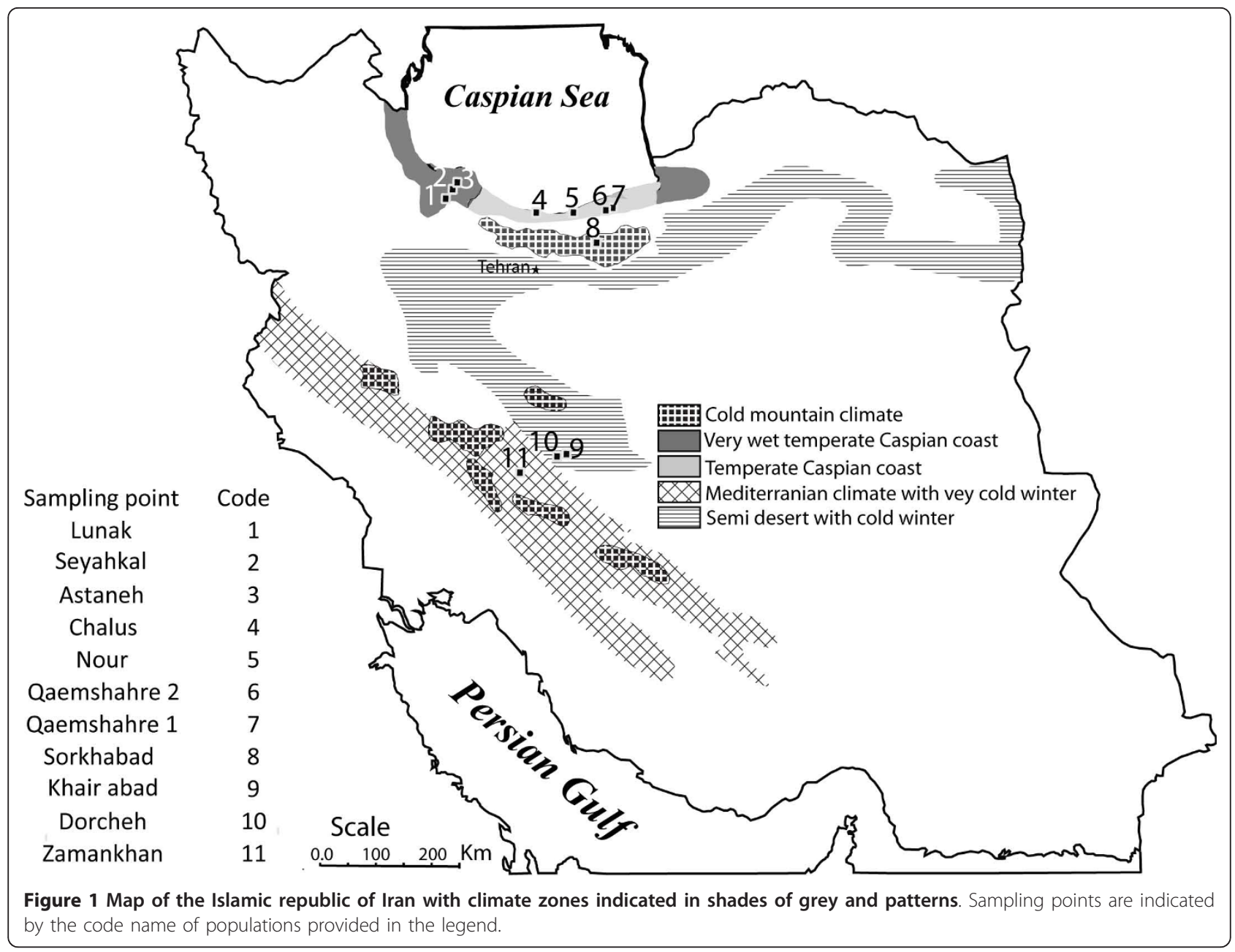

Table 1 Description of the trapping locations of the populations including climate, vegetation and elevation

\begin{tabular}{|c|c|c|c|c|c|}
\hline Zone & $\begin{array}{l}\text { Population } \\
\text { ID }\end{array}$ & Climate & Description of the location & Vegetation & $\begin{array}{l}\text { Elevation } \\
(\mathrm{m})\end{array}$ \\
\hline 1 & Sorkhabad & Mountain & $\begin{array}{l}\text { In the northern slope of the Damavand mountain, toward } \\
\text { Mazandaran province }\end{array}$ & $\begin{array}{l}\text { Tree and bushes along } \\
\text { the river }\end{array}$ & 1975 \\
\hline 2 & $\begin{array}{l}\text { Qaemshahr } \\
1\end{array}$ & Temperate wet forest & In Mazandaran province, coastal Caspian sea & Forest & 76 \\
\hline 2 & $\begin{array}{l}\text { Qaemshahr } \\
2\end{array}$ & Temperate wet forest & In Mazandaran province in coastal Caspian sea & Forest & 75 \\
\hline 2 & Nour & Temperate wet forest & In Mazandaran province in coastal Caspian sea & Natural park & 20 \\
\hline 2 & Chalus & Temperate wet forest & In Mazandaran province in coastal Caspian sea & Forest & 76 \\
\hline 3 & Astaneh & Temperate very wet forest & In Gilan province in coastal Caspian sea & $\begin{array}{l}\text { Windbreak of rice field, } \\
\text { close to city }\end{array}$ & 8.5 \\
\hline 3 & Seyahkal & Temperate very wet forest & In Gilan province in coastal Caspian sea & Very dense forest & 378 \\
\hline 3 & Lunak & Temperate very wet forest & In Gilan province in coastal Caspian sea & Very dense forest & 485 \\
\hline 4 & Dorcheh & $\begin{array}{l}\text { Semi dry desert with cold } \\
\text { winter }\end{array}$ & Close to Esfahan along the Zayandehrod river & Orchard along the river & 1625 \\
\hline 4 & Khairabad & $\begin{array}{l}\text { Semi dry desert with cold } \\
\text { winter }\end{array}$ & Close to Esfahan along the Zayandehrod river & $\begin{array}{l}\text { Orchard and field along } \\
\text { the river }\end{array}$ & 1605 \\
\hline 5 & Zamankhan & $\begin{array}{l}\text { Mediterranean with very } \\
\text { cold winter }\end{array}$ & Close to Shahre kord and along Zayandehrod river & $\begin{array}{l}\text { Orchard and field along } \\
\text { the river }\end{array}$ & 1873 \\
\hline
\end{tabular}




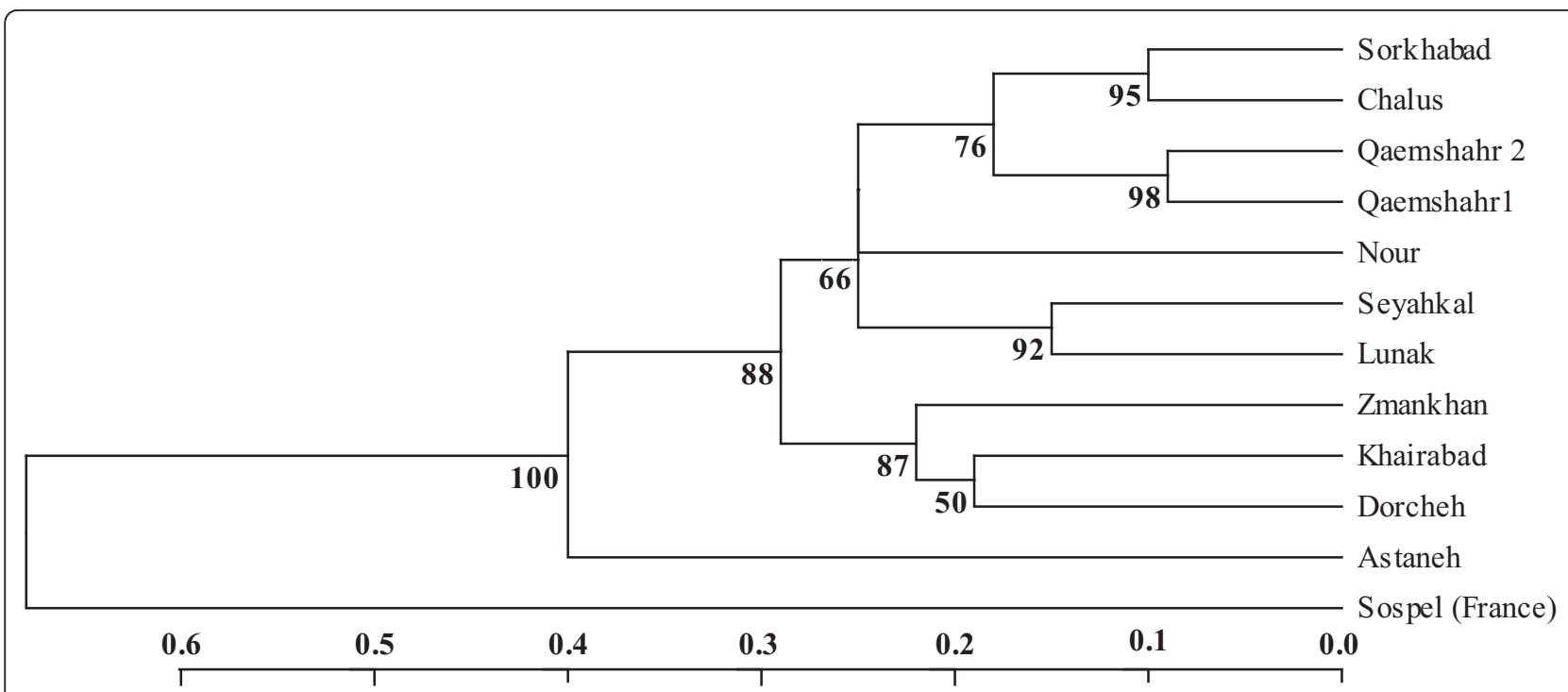

Figure 2 Dendogram derived from the UPGMA (unweighted pair group methods of arithmetic averages) analysis of 147 polymorphic AFLP bands. Shown are the genetic distances of 11 population of Iranian Leptopilina boulardi and their outgroup (a population of $L$. boulardi from France). Scales indicate genetic distances (Nei\& Li, 1979) and the numbers at nodes represent bootstrap value (1000 replicates).

\section{Isolation of populations by distance}

A significant positive correlation between genetic and geographic distance was observed among the L. boulardi populations (Mantel test; $\mathrm{r}=0.47, \mathrm{P}<0.001$ ). The result of this test showed that a considerable part of the genetic variation was explained by geographic distance and supported the UPGMA and Principal Coordinate analyses since all geographically-close populations resembled each other. The only exception was the population from Astaneh, which was highly distinct from all others populations, even from those collected from a distance of less than $15 \mathrm{~km}$. A partial Mantel test including all populations found no significant effect for isolation by the deserts of central Iran (mantel test; $\mathrm{r}=0.12, \mathrm{P}=0.25$ ). However, by excluding the Astaneh population from the partial Mantel test, we found a significant effect for isolation by dry desert (mantel test; $r=0.38$, $\mathrm{P}=0.001$ ). After correcting for the effect of isolation by desert, the partial correlation between geographic and genetic distances decreased somewhat, but still remained highly significant (mantel test; $r=0.41, \mathrm{P}=0.011$, Figure 4).

\section{Variation in cytochrome oxidase I (COI)}

COI sequence was found to be highly conserved among the Iranian $L$. boulardi populations. Only two bases were found to be different in two Caspian Sea coast populations and four insertions and one replacement were found in the out-group compared to the Iranian populations (Table 2).

\section{Discussion}

The AFLP analysis provided enough information to allow a clear distinction among $L$. boulardi populations originating from different climatic zones in Iran. With the exception of one population (Astaneh), the genetic distances between populations correlated closely with geographic distances. A partial Mantel test revealed a significant correlation between habitat isolation and genetic diversification. AMOVA also indicated diversification of populations originating from distinct dry or wet regions. Populations collected within short proximity tended to resemble each other genetically (e.g. Qaemshahr1 and Qaemshahr 2; distance $1.5 \mathrm{~km}$ ), as expected because of the high likelihood of gene flow. This was true even for populations that were ecologically very different: the mountain population of Sorkhabad was genetically indistinguishable from populations from the nearby coastal plain. The partial Mantel test showed significant effects of geographical barriers as well as the distance on genetic divergence. The positive correlation between genetic and geographic distances in our study is consistent with several other genetic structure studies $[11,13,21]$ on insect populations. However, studies on the genetic structure of Drosophila parasitoid populations are rare. A comparison of $L$. clavipes populations in western Europe found distinct genetic differentiation between sexual and asexual populations [22], but no correlation between geographic and genetic distances.

The different climatic environments we sampled (including desert, Mediterranean, and wet temperate conditions) undoubtedly impose different selection pressures on the life history of parasitoids. The genetic differences we observed between geographically isolated populations imply low gene flow. This will facilitate genetic response to such selection. 


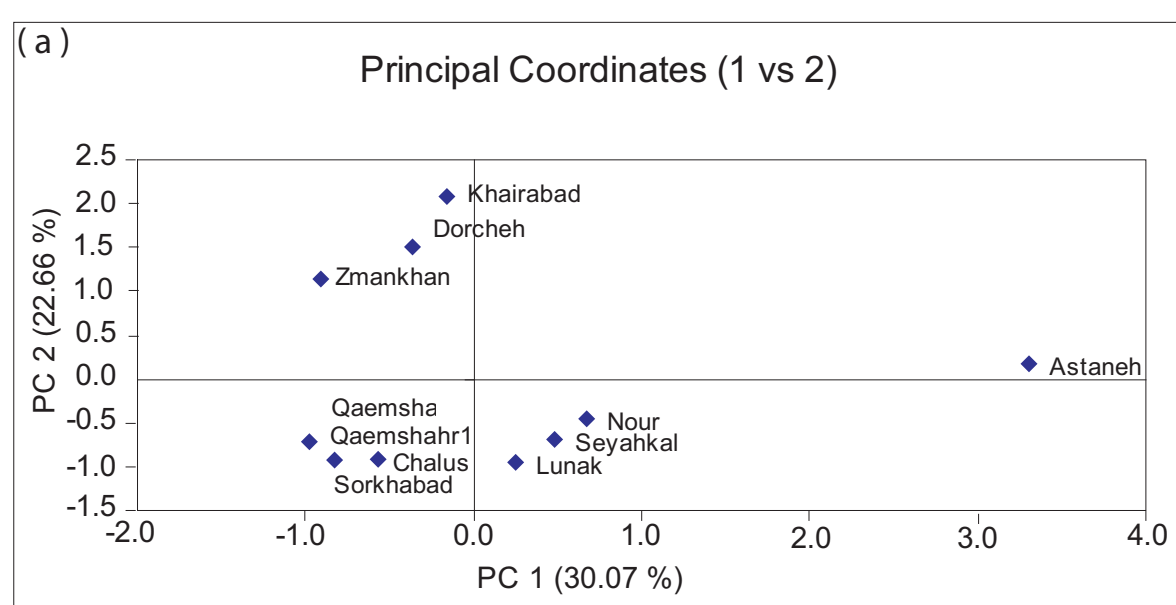

( b )
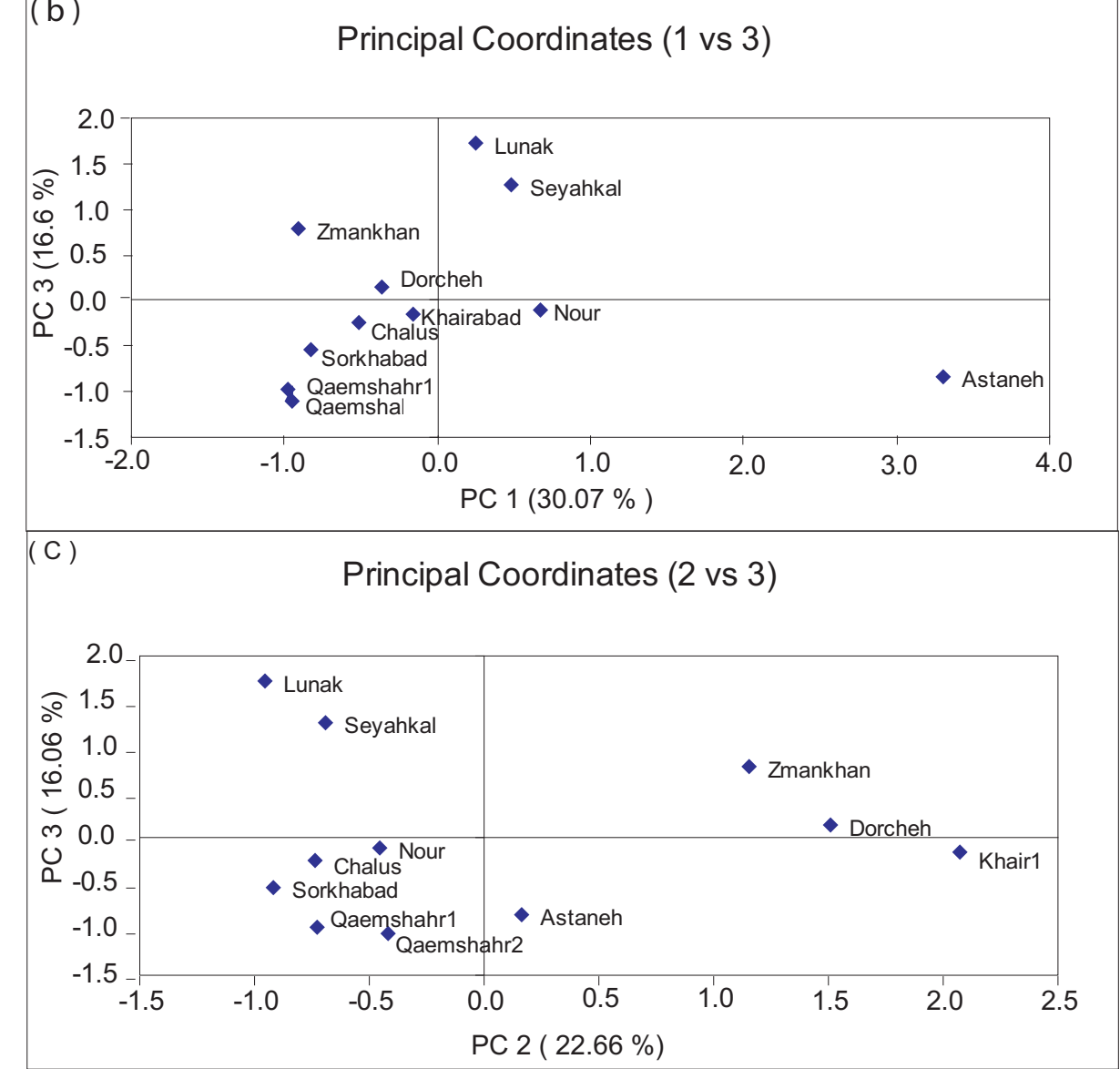

Figure 3 Separation of Iranian L. boulardi populations by the first three coordinates in Principal Coordinates analysis. The first three coordinates explained $69.23 \%$ of AFLP variations among Iranian L. boulardi populations. For the origin zone of populations see table 1.

In addition to geography and climate, human activity also appears to affect the genetic structure of L. boulardi populations. Parasitized fruit fly larvae may be transported with fruits and give rise to populations dissimilar from the neighbouring ones, in particular in urban areas. We found unexpected genetic divergence in two northern populations Astaneh (which was highly divergent from the neighbouring) and Nour (which showed intermediate structure between two Caspian Coast zones). Both populations originated from urban areas and could have arrived with fruit transports. 


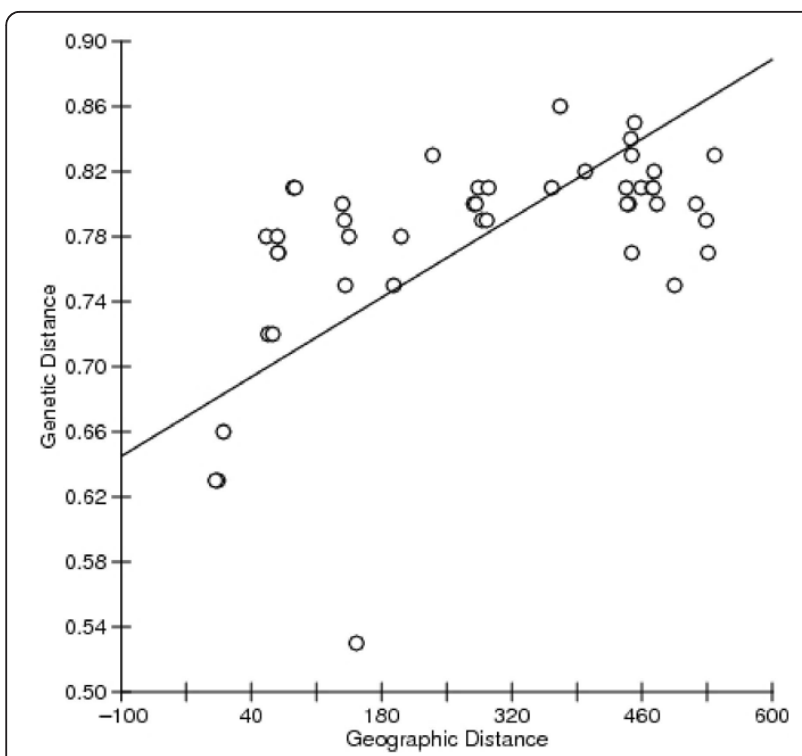

Figure 4 Partial correlation between genetic and geographic distances, excluding Astaneh, the most divergent population in all analyses.

In addition to geography and climate, variation in hosts may result in adaptation and genetic differentiation of parasitoids [23], due to the intimate relationship between host and parasitoid. However, we found no evidence of the differentiation caused by hosts in this study.

Populations in the central part of Iran were sampled from isolated locations surrounded by dry desert. The relatively high genetic divergence over relatively short geographic distance between these central populations compared to northern populations implies that the barrier formed by unsuitable habitat may contribute to genetic diversification independently of geographic distance (Figure 1, 2; compare geographic and genetic distances between Zamankhan and Dorcheh or Khairabad in central Iran to those between Qaemshahr1,2 and Chalus in the north).

Sequence data on the cytochrome oxidase I gene were less informative in our study than ALFPs. Mitochondrial markers are potentially informative markers in genetic studies of insect populations [15-17], sensitive to differences in the rates of male and female migration [24] between populations. However, most studies using CO I and II as molecular markers in insects have used them in phylogenetic and taxonomic contexts to discriminate between higher taxa [24-26] than populations. Our results demonstrate a highly conserved pattern for COI among L. boulardi populations.

\section{Conclusion}

In summary, this study provides strong evidence for genetic divergence of geographically isolated populations of $L$. boulardi from different climate zone of Iran. Geographic distance by itself explained a large amount of the variance in AFLP profiles. The two most distinct clusters, namely populations from central Iran versus those from the north, are also separated by a large area of unsuitable habitat, suggesting that such barriers may further contribute to genetic divergence. The mountain population from Sorkhabad showed that differences in ecology by themselves are not enough to overcome the homogenising effect of gene flow over short geographic distances. Climate may drive host distribution patterns and select for differences in life-history traits of parasitoids. The reduction in gene flow between geographically isolated populations will facilitate genetic adaptation to such selection pressures.

\section{Methods}

\section{Field sampling}

Leptopilina boulardi populations were sampled along a climatic cline stretching from the northern to the central regions of the Islamic Republic of Iran. The transect covered five climatic zones as follows (Table 1, Figure 1): cool mountains in Damavand (zone 1), wet forests (zone 2 ) and very wet rain forests along the Caspian sea coast (zone 3), a dry and hot climate with cold winters in the Esfahan region (zone 4) and a Mediterranean climate with very cold winters in Shahre Kord (zone 5). Sampling was conducted in mid-summer (July 2006) to increase the likelihood of collecting adult wasps from all the zones. At each sampling site, we placed 12 traps. The traps consisted of plastic containers (diameter 10 $\mathrm{cm}$; height $7.5 \mathrm{~cm}$ ) with a $3 \mathrm{~cm}$ diameter circular hole in the lid, which was covered with a plastic mesh wide

Table 2 Polymorphic site of the COI gene in 638 bp sequenced for 11 Iranian Leptopilina boulardi aligned with their out-group, Sospel- a population of $L$. boulardi from France

\begin{tabular}{llllllll}
\hline \multicolumn{7}{c}{ Position } \\
\hline Population & 10 & 60 & 131 & 321 & 338 & 440 & 459 \\
\hline Sospel & - & G & C & G & A & A & C \\
\hline Zamankhan & - & - & C & - & - & G & - \\
\hline Qaemshahr1 & - & - & C & - & - & G & - \\
\hline Qaemshahr2 & - & - & C & - & - & G & - \\
\hline Khairabad & - & - & C & - & - & G & - \\
\hline Dorche & - & - & A & - & - & G & - \\
\hline Nour & - & - & C & - & - & G & - \\
\hline Astaneh & - & - & C & - & - & G & - \\
\hline Seyahkal & - & - & C & - & - & G & - \\
\hline Lunak & - & - & C & - & - & G & - \\
\hline Sorkhabad & - & - & C & - & - & G & - \\
\hline Chalus & C & - & C & - & - & G & - \\
\hline
\end{tabular}


enough for Drosophila flies and their parasitoids to enter the traps. Several layers of filter paper were placed in each trap to absorb water and provide pupation sites for Drosophila larvae. The traps were baited with a piece of banana and suspended from trees and its position was recorded by GPS (Additional file 2). After a week the traps were collected and all pupae in the traps were wrapped in filter paper and transferred to the lab. Leptopilina boulardi was the only parasitoid collected from all locations. Partially inbred lines were set up from each sampling site and 20 female wasps per population from early generations were frozen at $-80^{\circ} \mathrm{C}$ for genetic analysis.

\section{DNA extraction}

Five female wasps in four replications were pooled per strain for DNA extraction using an adapted CTAB protocol for insects [27], including an extra RNase A step. The quality of the extracted DNA was checked on a $0.8 \%$ agarose gel and its quantity measured by a spectrophotometer (ND-1000, http://www.nanodrop.com ). In the case of low quantity or sheared DNA the DNA extraction was repeated using five new females from the same strain.

\section{AFLP analysis}

To assess the genetic diversity of the L. boulardi populations, we employed the Amplified Fragment Length Polymorphism (AFLP) technique [10] with a slight modification to the standard procedure. Approximately $500 \mathrm{ng}$ of genomic DNA was incubated with EcoRI and MseI enzymes (New England Biolabs:http://www.neb. com). EcoRI/MseI adaptors were ligated to the restriction fragments. Preamplification was conducted using EcoRI $+\mathrm{A}$ and $\mathrm{Mse}+\mathrm{C}$ primers (Table 3). A touchdown profile amplification during which the annealing temperature was dropped by $0.7^{\circ} \mathrm{C}$ in each cycle was used to increase the optimal primer selectivity in this step. Selective amplification was performed using one of three

Table 3 List of primers and adaptor used for the AFLP analysis

\begin{tabular}{lll}
\hline Type & Name & Sequence 5'-3' $^{\prime}$ \\
\hline Adaptor & EcoRl adaptor/F & CTCGTAGACTGCGTACC \\
& EcoRl adaptor/R & AATTGGTACGCAGTCTAC \\
& Msel adaptor/F & GACGATGAGTCCTGAG \\
& Msel adaptor/R & TACTCAGGACTCAT \\
\hline Primer, pre select. amp. & EcoRl Preamp. & GAC TGCGTACCAATTCA* \\
& Msel Preamp. & GATGAGTCCTGAGTAAC* \\
\hline Primer, select. amp & EcoRl Select. & GACTGCGTACCAATTCANN * \\
& Msel Select. & GATGAGTCCTGAGTAACN * \\
\hline
\end{tabular}

*Nucleotides in bold are the fixed extended base in the 3 ' end of the primers and $\mathrm{N}$ are the variable extension to provide different primer combination, see above.
EcoRI primers (fluorescently labeled) and one of three MseI with three and two base extensions in each primer respectively. Different combinations of these primers resulted in 9 useful primer combinations (Table 4).

PCR products from the selective amplification were purified run on a DNA sequencher MegaBACE ${ }^{\text {TM }} 1000$ system (Amersham Pharmacia USA, http://www.gelifesciences.com/aptrix/upp01077.nsf/Content/life-sciences_ homepage at $10 \mathrm{kV}$ for $75 \mathrm{~min}$. The fluorescent profiles were loaded into Fragment Profiler ${ }^{\mathrm{TM}}$ software ver1.2 (Amersham, Biosciences, http://www.amersham.com) using specific peak filters and were manually checked for correct alignment of the size standard. The positions of polymorphic markers between 80 and 500 bp were scored and exported as a binary matrix in an excel sheet.

\section{Amplification and sequence alignment for $\mathrm{COI}$}

A 638 bp portion of the cytochrome oxidase subunit I (COI) gene was amplified for three individuals per strain to evaluate the mitochondrial variation among the 11 Leptopilina boulardi populations from Iran. A L. boulardi population from Sospel (France) was used as outgroup. PCR amplification was performed using a forward primer designed by Scheffer and Grissell [28], COI-1775-F 5'CGAATAAATAATATAAGATTTTG-3 and a reverse primer designed for Leptopilina clavipes (K. Kraaijeveld, unpublished), COI-2413-R, 5'-TCATCTAAAAATTTTAATCCCAGT-3'. The amplification was carried out on a Thermocycler PTC-2000 using the following thermal cycles: $3 \mathrm{~min}$ at $92^{\circ} \mathrm{C}$ followed by a touchdown with one degree drop in annealing temperature per cycle from $53-40^{\circ} \mathrm{C}\left(10 \mathrm{sec}\right.$ at $92^{\circ} \mathrm{C}, 10 \mathrm{sec}$ at $53-40^{\circ} \mathrm{C}$ and $2 \mathrm{~min}$ at $72^{\circ} \mathrm{C}$ ), then 25 cycles of $10 \mathrm{sec}$ at $92^{\circ} \mathrm{C}, 10 \mathrm{sec}$ at $40^{\circ} \mathrm{C}$ and $2 \mathrm{~min}$ at $72^{\circ} \mathrm{C}$, ending with 5 min extension at $72^{\circ} \mathrm{C}$. Each PCR reaction contained 1.2 $\mu \mathrm{l}$ of $2.5 \mathrm{mM}$ DNTPs, $0.5 \mu \mathrm{l}$ of $10 \mu \mathrm{M}$ of each primer, $0.15 \mu \mathrm{l}$ of Taq DNA polymerase $(5 \mathrm{U}), 1.5 \mu \mathrm{l}$ of $10 \mathrm{X}$ Buffer and $0.45 \mu \mathrm{l}$ of $15 \mathrm{mM} \mathrm{MgCl} 2 \mu \mathrm{l}$; all Qiagen products and was adjusted to $15 \mu \mathrm{l}$ with autoclaved nanopure water. The PCR products were purified using Wizard SV Gel and PCR Clean-Up System (Promega, http:// www.promega.com ) following the manufacturer's protocol. The amplified bands were sequenced both forward and reverse on MegaBACE 1000 sequencher. The Sequencher software Version 4.2 (Gene Codes Corp.) was used to assemble the contigs and obtain consensus sequences. The sequences were aligned using pairwisealignment in MacClade 4.08 [29] and edited manually.

\section{Data analysis}

Population structure was investigated using a molecular variance software package (AMOVA) and $F_{s t}$ statistics were estimated using ARLEQUIN software [30,31], ver. 3.5. Pair-wise genetic distances between populations 
Table 4 List of selective amplification primers and fluorescent labels used in nine different combinations and the number of scorable and polymorphic bands generated by each combination

\begin{tabular}{llll}
\hline Combination & Primers and labels & Scored band & polymorphic band \\
\hline A & EcoRI+ACA (labeled Fam), Msel+CA & 117 & $22(18.8 \%)$ \\
B & EcoRI+AGG (labeled Joe), Msel+CA & 63 & $20(31.74 \%)$ \\
C & EcoRI+AAC (labeled Ned), Msel+CA & 65 & $12(18346 \%)$ \\
D & EcoRI+ACA (labeled Fam), Msel+CT & 101 & $15(14.85 \%)$ \\
E & EcoRI+AGG (labeled Joe), Msel+CT & 65 & $25(38.46 \%)$ \\
F & EcoRI+AAC (labeled Ned), Msel+CT & 58 & $11(18.96)$ \\
G & EcoRI+ACA (labeled Fam), Msel+CG & 80 & $14(17.5 \%)$ \\
H & EcoRI+AGG (labeled Joe), Msel+CG & 69 & $16(23.19 \%)$ \\
I & EcoRI+AGG (labeled Joe), Msel+CC & 52 & $12(23.08 \%)$ \\
Total band & & 670 & 147 \\
\hline
\end{tabular}

were calculated from the AFLP data using Nei and Li's index [32] in Treecon version 1.3b [33] for windows. UPGMA cluster analysis [34] with 1000 replications of bootstraps was performed in Treecon and genetic distances were visualized in a dendrogram format. The geographic distances between collecting sites were calculated from their GPS locations and combined with the genetic distance values into a pair-wise genetic and geographic distance matrix. We set an indicator as isolated (1) or connected (0) for the isolation by unsuitable habitat in to $0 / 1$ binary character matrix. Isolation by distance and geographical barrier was investigated with a partial Mantel test [35] using the web-based program Isolation by distance web service (IBDWS) [36] version 3.16. The combined binary AFLP data matrix was used to perform Principal Coordinate analysis (PCO) with GenAlex 6 [37] using Nei and Li's coefficient [32] for calculating similarities, three first coordinates were used to graphically depict genetic variation among populations.

\section{Additional material}

Additional file 1: Fst and $\mathrm{P}$ value for pair wise comparison of populations. Below diagonal Fst value and above $\mathrm{P}$ value of pair wise comparison of populations derived from AMOVA of AFLP results of eleven populations of Leptopilina boulardi from Iran.

Additional file 2: Sampling points. Sampling points and their GPS coordinates, climate zone and elevation above sea level.

\section{Acknowledgements}

We would like to express our special thank to Dr. Klass Vrieling for helping us in analysing the AFLP data. We would like to thanks the Agricultural Research and Education Organization (AREO) of Iran for funding the project and Iranian Research institute of Plant Protection for hosting us during the much of the field work. We also would like to thanks Mr. Jahangir Khajehal in Isfahan University of Technology for close collaboration during the field work in Islamic Republic of Iran.

\section{Author details}

${ }^{1}$ Institute of Biology, Leiden University, P.O.Box 9505, 2300 RA Leiden, the Netherlands. ${ }^{2}$ Agricultural Research Center of Hormozgan, P.O.Box 79145/
1577, Bandar Abbas, Iran. ${ }^{3}$ Institute for Biodiversity and Ecosystem Dynamics, P.O.Box 94248, 1090 GE Amsterdam, the Netherlands.

\section{Authors' contributions}

MAS designed the project, collected samples in the field collected and analysed the data and wrote the manuscript. JJMvA participated in the field work, supervised project and improved the manuscript. KK helped in improving methodology and data analysis, supervised the project and improved the manuscript. All authors read and approved the final version.

Received: 29 May 2010 Accepted: 27 January 2011

Published: 27 January 2011

\section{References}

1. Slatkin M: Gene flow and the geographic structure of natural populations. Science 1987, 236:787-792.

2. Peterson MA, Denno RF: The influence of dispersal and diet breadth on patterns of genetic isolation by distance in phytophagous insects. Am Nat 1998, 152:428-446.

3. Mopper S, Strauss SY: Genetic structure and local adaptation in natural insect populations: effects of ecology, life history and behavior. New York Chapman and Hall; 1998.

4. Reineke A, Karlovsky P, Zebitz CPW: Amplified fragment length polymorphism analysis of different geographic populations of the gypsy moth, Lymantria dispar (Lepidoptera: Lymantridae). Bull Entomol Res 1999, 89:79-88.

5. Samara R, Monje JC, Reineke A, Zebit CPW: Genetic divergence of Trichogramma aurosum Sugonjaev and Sorokina (Hymenoptera: Trichogrammatidae) individuals based on ITS2 and AFLP analysis. J Appl Entomol 2008, 132:230-238.

6. McMichael M, Prowell DP: Differences in amplified fragment length polymorphisms in fall army worm (Lepidoptera: Noctudiae) host strains. Ann Entomol Soc Amer 1999, 92:175-181.

7. Hawthorne DJ: AFLP-based genetic linkage map of the Colorado potato beetle Leptinotarsa decemlineata: Sex chromosomes and a pyrethroidresistance candidate gene. Genetics 2001, 158:695-700.

8. Wu YQ, Huang YH, Tauer CG, Porter DR: Genetic diversity of sorghum accession resistant to green bugs as assessed with AFLP Markers. Genome 2006, 49:143-149.

9. Tao J, Ai Y, Luo Y, Yang L, Yan W, Chen M: AFLP analysis of genetic variation of Hyphantriacunea (Drury) populations in Beijing and a nearby site. Forestry Studies in China 2009, 11:14-19.

10. Vos $P$, Hogers $R$, Bleeker M, Reijans M, Vam de Lee T, Hornes M, Frijters A Pot J, Peleman J, Kuiper M, Zebeau M: AFLP: a new technique for DNA fingerprinting. Nucleic Acids Res 1995, 23:4407-4414.

11. Salvato P, Battisti A, Concato S, Masutti L, Patarnello T, Zane L: Genetic differentiation in the winter pine processionary moth (Thaumetopoea pityocampa-wilkinsoni complex), inferred by AFLP and mitochondrial DNA markers. Mol Ecol 2002, 11:2435-2444.

12. Irwin DE, Bensch S, Irwin JH, Price TD: Speciation by Distance in a Ring Species. Science 2005, 307:414-416. 
13. Clark RG, Shutler D: Avian Habitat Selection: Pattern from Process in Nest-Site Use by Ducks? Ecology 1999, 80:272-287.

14. Han ZQ, Lin LS, Shui BN, Gao TX: Genetic diversity of small yellow croaker Larimichthys polyactis revealed by AFLP markers. Afr J Agric Res 2009, 4:506-610.

15. Crozier RH, Oldroyd BP, Tay WT, Kaufmann BE, Johnson RN, Carew ME, Jennings KM: Molecular advances in understanding social insect population structure. Electrophoresis 1997, 18:1672-1675.

16. Olav R: Mitochondrial markers in the ant Leptothorax rugatulus reveal the population genetic consequences of female philopatry at different hierarchical levels. Mol Ecol 2003, 12:795-801.

17. Smith PT: Mitochondrial DNA variation among populations of the glassywinged sharpshooter, Homalodisca coagulata. J. Insect Sci 2005, 41:1-8.

18. Godfray HCJ, Shimada M: Parasitoids: a model system to answer questions in behavioral, evolutionary and population ecology. Res Popul Ecol 1999, 41:3-10.

19. Irving $P$, Troxler $L$, Hetru $C$ : Is innate enough? The innate immune response in Drosophila. C R Biol 2004, 327:557-570.

20. Allemand R, Lemaitre C, Frey F, Bouletreau M, Vavre F, Nordlander G, van Alphen JJM, Carton Y: Phylogeny of six African Leptopilina species (Hymenoptera: Cynipoidea, Figitidae), parasitoids of Drosophila, with descriptions of three new species. Ann Soc Entomol Fr 2003, 38:319-332.

21. Kerdelhue C, Magnoux E, Lieutier F, Roques A, Rousselet J: Comparative population genetic study of two oligophagous insects associated with the same hosts. Heredity 2006, 97:38-45.

22. Pannebakker BA, Zwaan BJ, Beukeboom LW, van Alphen JJM: Genetic diversity and Wolbachia infection of the Drosophila parasitoid Leptopilina clavipes in western Europe. Mol Ecol 2004, 13:1119-28.

23. Althoff DM: A test of host-associated differentiation across the 'parasite continuum' in the tri-trophic interaction among yuccas, bogus yucca moths, and parasitoids. Mol Ecol 2008, 17:3917-3927.

24. Lunt DH, Zhang DX, Szymura JM, Hewitt GM: The insect cytochrome oxidase I gene: evolutionary patterns and conserved primers for phylogenetic studies. Insect Mol Biol 1996, 5:153-165

25. Caterino MS, Sperling FAH: Papilio Phylogeny Based on Mitochondrial Cytochrome Oxidasel and II Genes. Mol Phylogenet Evol 1999, 11:122-137.

26. Zaldivar-Riverón A, Mori M, Quicke DL: Systematics of the cyclostome subfamilies of braconid parasitic wasps (Hymenoptera: Ichneumonoidea): A simultaneous molecular and morphological Bayesian approach. Mol Phylogenet Evol 2006, 38:130-145.

27. Reineke A, Karlovsky P, Zebitz CP: Preparation and purification of DNA from insects for AFLP analysis. Insect Mol Biol 1998, 7:95-99.

28. Scheffer SJ, Grissell EE: Tracing the geographical origin of Megastigmus transvaalensis (Hymenoptera: Torymidae): an African wasp feeding on a South American plant in North America. Mol Ecol 2003, 12:415-421.

29. Maddison DR, Maddison WP: MacClade 4: Analysis of Phylogeny and Character Evolution. Sunderland, MA, Sinauer Associates; 4.082005 [http:// macclade.org].

30. Excoffier L, Laval G, Schneider S: Arlequin (version 3.0): an integrated software package for population genetics data analysis. Evol Bioinform Online 2005, 1:47-50.

31. Excoffier L, Lischer HEL: Arlequin suite ver 3.5: A new series of programs to perform population genetics analyses under Linux and Windows. Mol Ecol Resour 2010, 10:564-567.

32. Nei M, Li WH: Mathematical model for studying genetical variation in terms of restriction endonucleases. Proc Natl Acad Sci USA 1979, 76:5269-5273.

33. van der Peer $Y$, de Wachter RD: TREECON for Windows: a software package for the construction and drawing of evolutionary trees for the Microsoft Windows environment. Computational Applications in Biosciences 1994, 10:569-70.

34. Sokal RR, Michener CD: A statistical method for evaluating systematic relationships. University of Kansas Science Bulletin 1958, 38:1409-143.

35. Mantel $\mathrm{N}$ : The detection of disease clustering and a generalized regression approach. Cancer Research 1967, 27:209-220.

36. Jensen JL, Bohonak AJ, Kelley ST: Isolation by distance, web service. BMC Genetics 2005, 6:13

37. Peakall R, Smouse PE: GENALEX 6: genetic analysis in Excel. Population genetic software for teaching and research. Mol Ecol Notes 2006, 6:288-295 [http://www.anu.edu.au/BoZo/GenAlEX]. doi:10.1186/1472-6785-11-4

Cite this article as: Seyahooei et al: Genetic structure of Leptopilina boulardi populations from different climatic zones of Iran. BMC Ecology 2011 11:4.

\section{Submit your next manuscript to BioMed Central and take full advantage of:}

- Convenient online submission

- Thorough peer review

- No space constraints or color figure charges

- Immediate publication on acceptance

- Inclusion in PubMed, CAS, Scopus and Google Scholar

- Research which is freely available for redistribution

Submit your manuscript at www.biomedcentral.com/submit
Biomed Central 